\title{
Expanding the nation's oil and gas market through consolidated refining: a better option to achieve surplus of refined petroleum products
}

\begin{abstract}
The deregulation and diversification of oil and gas downstream sector of the nation's economy are the best option which can lead to achieving efficiency in process petroleum refining and in turn exportation of refined crude. Currently, Nigeria has four-refineries (Kaduna refinery and petrochemical company, KRPC; two-Port Harcourt refinery company, PHRC; and Warri refinery and petrochemical company WRPC) which are operating below the installed capacities. However, qualitative and transparent deregulations of the downstream sector can be achieved through viable policies that are resounding voices representing all the stakeholders in the oil and gas sector. When consolidation of refined oil and gas is achieved, the result would be the surplus petroleum products, for example, $905,130 \mathrm{bpd}$ will resolve the problem of domestic consumptions, possible reduction in prices of refined petroleum products and in turn increase the nations' gross domestic product (GDP), due to the exportation of refined crude.
\end{abstract}

Keywords: oil and gas, refined petroleum products, investment, GDP
Volume 2 Issue 6 - 2017

\author{
MN Idris, ${ }^{1,2}$ AS Ahmed, ${ }^{3}$ IA Ibafe ${ }^{4}$ \\ 'Department of Chemical Engineering, University of Maiduguri, \\ Nigeria \\ ${ }^{2}$ Energy Resource Research Institute, EERI, University of Leeds, \\ UK \\ ${ }^{3}$ Department of Chemical Engineering, ABU Zaria, Nigeria
}

${ }^{4}$ Department of Chemical Engineering, UNIBEN, Benin, Nigeria

\begin{abstract}
Correspondence: MN Idris, Department of Chemical Engineering, University of Maiduguri, Nigeria, Energy Resource Research Institute, EERI, University of Leeds, UK, Tel +234 (0)
\end{abstract} 705877 1096,Email muhinu@hotmail.co.uk

Received: June 16, 2017 | Published: July 26, 2017
Abbreviations: Bpd, barrel per day; CCC, chiyoda chemical company ltd; EPCL, eleme petrochemical company ltd; ERRI, energy resource research institute; GDP, gross development company; IDSL, integrated data services ltd; KRPC; kaduna refinery and petrochemical company; MDG, millennium development goal; MOU, memorandum of understanding; NAPIMS, National petroleum and investment company; NETCO, national engineering and technical company; NGC, national gas company; NLC, nigerian labor congress; NPDC, national petroleum development company; NNPC, nigerian national petroleum corporation; PHRC, port harcourt refinery and petrochemical company; PMS, premium motor spirit; PPPRA, petroleum pump price regulatory agency; PPMC, pipelines and products marketing company; TUC, trade union congress; WRPC, warri refinery and petrochemical company

\section{Introduction}

The constructions and full operations of the first phase of the Nigerian refineries (KRPC Kaduna, PHRC Port Harcourt, and WRPC Warri) started in the early late 70's. However, the expansion and the second phase (New PHRC refinery and the construction of KRPC linear alkyl benzene plant) came into being in the early 1990's. Today, almost all these refineries operate below $50 \%$ of the design/operating capacity. This is a very alarming problem in the Nigeria nation because older refineries (in the UK, USA, Saudi Arabia, France, Germany etc.) across the globe are still operating with good performance within the design/installed capacities. The best strategy to re-stream the Nigerian refineries to full capacity of operation is to invite the construction firms (Chiyoda Chemical Company Japan and others) and all interested foreign investors. Furthermore, a suggestion to construct additional 6-new refineries would be of great significance in the development of the downstream sector of the company across the nation. However, this re-streaming and construction of new refineries cannot be achieved by the government alone. Therefore, the need for deregulations of the downstream sector of the economy is a welcome phenomenon that will provide the government huge savings which can be used to develop all virgin areas of the economy, the building of infrastructures and training manpower for greater development.

This paper is presented to identify the problems facing the Nigerian refineries, possible ways out of the predicament and investment opportunities in the downstream sector. When the identified steps were correctly implemented, the end results would be a vibrant economy and increase in the nation's GDP and in turn providing employment opportunities to our young graduates.

\section{The NNPC refineries operations}

The Nigerian national petroleum corporation (NNPC) is the government umbrella body on petroleum operations in Nigeria. ${ }^{1}$ The downstream industry in Nigeria is well established and currently, the NNPC has 11-subsidiaries which include; Hyson, IDSL, KRPC, NETCO, NGC, NPDC, NAPIMS, PHRC, PPMC, EPCL, and WRPC. The NNPC has four functional refineries although operating below design/operating capacities. The KRPC Kaduna, two-PHRC Port Harcourt, and WRPC Warri have a combined installed capacity of 445,000 bpd, NNPC website. A comprehensive network of pipelines and depots strategically located throughout Nigeria links these refineries. Table 1 represents the designed/installed and current operating capacities of the 3-refineries of NNPC.

The KRPC produces linear alkyl benzene (LAB), benzene, heavy alkylate and deparafinated kerosene at its Kaduna Refinery complex. The PHRC has the largest design capacity among the three refineries aiming at providing the nation with domestic PMS consumption. However, their operations below the installed capacity are situation which must be fully re-streamed to achieve the quality 
and quantity target for the nation. The WRPC has 35,000 metric ton per annum (mtpa) of polypropylene processing plant and an 18,000 mtpa carbon black plant. ${ }^{2} 2.1$ Re-streaming Nigerian Refinery to Full Operating Capacity and Investment in Downstream Sector The Federal Government initial approach toward revitalising the nation's downstream processing system is much welcome by inviting the refineries conceptual designer and construction company (Chiyoda Chemical Company, (CCC), Tokyo Japan), because their unique technology which should be studied by the Nigerian young engineers and scientist. Employing of fresh and young brains amongst the Nigerian graduates and skilled youth to acquire experience from the foreign experts through train-the-trainer scheme must be initiated and instituted. In the course of achieving this target, there would be a qualitative hand that would be able to manage the re-streamed refineries properly. In the advent of inviting the Chiyoda Company, a memorandum of understanding, MOU should be reached as follows:

i. They should use and/or source the local material as where possible.

ii. They should work closely with our indigenous engineers and technologist in the design and construction.

iii. If possible they should have an extension of their services permanently in Nigeria.

iv. All design and construction procedure should be provided to our engineers and technologist.

v. Expert and free advice services toward sustainability of the refineries as when due.

vi. Seconded staff of the Chiyoda Company to the refinery should be considered.

Table I Current operation of the 3-refineries of the NNPC

\begin{tabular}{|c|c|c|c|c|}
\hline \multirow[t]{2}{*}{$\begin{array}{l}\text { NNPC } \\
\text { refinery }\end{array}$} & \multicolumn{2}{|c|}{$\begin{array}{l}\text { Design/Installed } \\
\text { capacities }\end{array}$} & \multicolumn{2}{|c|}{ Operating capacities } \\
\hline & $\begin{array}{l}\text { barrel/day } \\
\text { (bpd) }\end{array}$ & $\begin{array}{l}\text { Percent } \\
\text { (\%) }\end{array}$ & $\begin{array}{l}\text { barrel/day } \\
\text { (bpd) }\end{array}$ & $\begin{array}{l}\text { Percent } \\
\text { (\%) }\end{array}$ \\
\hline KRPC & 133,500 & 30 & 60,075 & 45 \\
\hline PHRC & 178,000 & 40 & 97,900 & 55 \\
\hline WRPC & 133,500 & 30 & 80,100 & 60 \\
\hline Total & 445,000 & 100 & 238,075 & 53.5 \\
\hline
\end{tabular}

Source: NNPC

From Table 2, it is observed that after restreaming the 3-refineries a net increase in production operations $140,175 \mathrm{bpd}$, this is based on grand percentage of $85 \%$ operating capacities. The $85 \%$ is set as the minimum achievable of the refinery restreaming. However, they exceed the $85 \%$ criteria of the operating capacities that is $85-95 \%$ operations, the net increase in production would be above 140,175 184,675 bpd.

\section{The local contents usage}

The enacted of local content law is an aforementioned step toward foreign dependence on expatriates to import goods and services from overseas. Driving the local contents and the use of indigenous technology in the restreaming the existing refineries and the constructions of new ones is an added advantage. Among the benefits these would bring to the nation are as follows:

a. The progressive growth of the nation's economy through technology and innovations.

b. It equally creates job opportunities to the teaming Nigerian youths.

c. Way to expand and diversify the research and development, R \& $\mathrm{D}$ of the oil and gas sector of the economy.

d. It helps in the utilization of Nigeria human and material resources.

e. It increases the investment in the local facilities.

f. Increase the training capacity of the young engineers, scientist and the technologist in the oil and gas sector.

g. An easy way to develop the other sector of the economics, e.g. transport and health sectors of the economy.

Table 2 Possible operation after restreaming of the 3-refineries of the NNPC

\begin{tabular}{lllll}
\hline $\begin{array}{l}\text { NNPC } \\
\text { refinery }\end{array}$ & $\begin{array}{l}\text { Design/Installed } \\
\text { capacities }\end{array}$ & Operating capacities \\
& barrel/day & $\begin{array}{l}\text { Percent } \\
(\%)\end{array}$ & barrel/day & $\begin{array}{l}\text { Percent } \\
(\%)\end{array}$ \\
\hline KRPC & 133,500 & 30 & 113,475 & 85 \\
PHRC & 178,000 & 40 & 151,300 & 85 \\
WRPC & 133,500 & 30 & 113,475 & 85 \\
Total & $\mathbf{4 4 5 , 0 0 0}$ & 100 & $\mathbf{3 7 8 , 2 5 0}$ & $\mathbf{8 5}$ \\
\hline
\end{tabular}

Source: NNPC

\section{Construction of 6-new refineries in the six- -geographical zones}

Nigeria's population is about 162 million with possible growth rate of $3.2-5 \%$ yearly. ${ }^{3}$ The nation is classified as the sixth largest population in the world. The drive to cushion the effect of any developing nation is to inculcate the population growth in the planning of her development strategy. We have identified that even if all the current 4-refineries are operating on full capacities, the refined products cannot solve the domestic demands. Therefore, the needs to construct new refineries each in the six-geopolitical zones namely; South-South SS, South-East SE, South-West SW, North-Central NC, North-East NE and North-West NW. The importance of constructing new refineries to each of the six-geographical zones will successfully cushion the shortfall on the domestic demand of the refined crude and stoppage on the importation of petroleum products into the country. From Table 3, a net production of the PMS of 764,955 bpd would be achieved from the proposed 6-newly constructed across the sixgeopolitical zones operating at equal capacities.

\section{The petroleum subsidy}

Petroleum subsidy is the fund paid by the Federal Government to an argument the real price of refined crude. In Nigeria, before 
December 31, 2011, the price of premium motor spirit (PMS) was N65 per liter, but due to the removal of subsidy the price become N141 per liter. When a total subsidy, was removed, the governments were saving a sum of N76 on ever liter of PMS. The deregulation of the downstream sector of the economy is not only centered of subsidy removal but also the removal of refined crude monopoly and possible reduction in premium motor spirit (PMS) price. More so, the implementation of subsidy removal by the Federal Government should be judiciously channeled to re-develop areas which would have positive effects like increase in educational funding, improving health sector funding, constructions and rehabilitation of roads, rural and urban infrastructural development and creation of employment to the teaming Nigeria through local initiatives.

Table 3 Profile of the proposed 6-refinery operations in the six geopolitical zones

\begin{tabular}{lllll}
\hline $\begin{array}{l}\text { NNPC } \\
\text { refinery }\end{array}$ & $\begin{array}{l}\text { Design/Installed } \\
\text { capacities }\end{array}$ & $\begin{array}{l}\text { Operating } \\
\text { capacities }\end{array}$ & \\
& barrel/day & $\begin{array}{l}\text { Percent } \\
(\%)\end{array}$ & barrel/day & $\begin{array}{l}\text { Percent } \\
\text { (\%) }\end{array}$ \\
\hline NC & 133,500 & 16.7 & $127,492.5$ & 16 \\
NE & 133,500 & 16.7 & $127,492.5$ & 16 \\
NW & 133,500 & 16.7 & $127,492.5$ & 16 \\
SE & 133,500 & 16.7 & $127,492.5$ & 16 \\
SW & 133,500 & 16.7 & $127,492.5$ & 16 \\
SS & 133,500 & 16.7 & $127,492.5$ & 16 \\
Total & $\mathbf{8 0 1 , 0 0 0}$ & 100 & $\mathbf{7 6 4 , 9 5 5 . 0}$ & 96 \\
\hline
\end{tabular}

The subsidy removal and the nation's economy

The immediate effect of the fuel subsidy removal was the reactions of the Nigerian people and the nation's economy hardship. The reason the whole Nigerian felt is because the policies were implemented immaturely. The response actions of the masses was the strike actions of the Nigeria labor Congress (NLC), Trade union Congress (TUC) and other civil society groups which brought the nation to a standstill between 9 th -15 th January 2012. The subsequent effect of these strike action is the breakdown of law and order which further treating the fragile sovereignty and increase in the insecurity of the nation. Consequently, as at Monday $16^{\text {th }}$ January 2012, the federal government announce through the petroleum pump price regulatory agency (PPPRA), the partial removal of subsidy in order to alleviate the hardship of the masses. Currently in the fiscal year 2016, the official pump price of PMS in Nigeria N145 per liter. Although, some petrol station is selling below benchmark price due to base location and other advantages. Indeed, the strike action in 2012 could have been averted if proper steps and action toward the fuel subsidy removal were implemented. It was reported by the National Bureau of Statistics (NBS) that Nigeria lost about N207 billion to within 8-days of the strike. The NBS report equally shows that the whole and retail sales which contribute about 18 percent to the GDP was worst hit by the strike compared to other sectors which recorded a loss of approximately N86,981.84 million. ${ }^{4}$

\section{Transparency in policies and gradual removal of sub- sidy}

All prospering nation achieve successes due to quality and transparent policies that progress development. Proper considerations of all the stakeholders in policy formulations and their implementation with effective communications are a better way to reach compromise in the event of a misunderstanding. ${ }^{5,6}$ The Nigerian masses may have felt that in reality, the Federal Government policy on subsidy removal is ill-timed. However, gradual removal of subsidy within a time-frame would have directed a better option and the sudden removal in totality. This paper suggests a better approach to the issue of subsidy removal as follows:

Transparency of policy: Transparency in policy application and implementation is another problem the masses have observed. The reasons were because of the previous policies, like the removal of subsidy on kerosene, which also has a direct adverse effect on the masses, and until this moment the availability of kerosene is a mirage in Nigeria.?

Gradual removal of subsidy: The removal of petroleum subsidy should be a gradual scheme with caution within a specific period of time would have been the best option, e.g. for a period of $12-24$ months. These would save the country and the government from many pressures, such as insecurity through the breakdown of law and order, an imbalance in the economy through strike actions etc.

Money saved from subsidy: A reasonable percentage of the accrued savings from subsidy removal should be assigned to a special and dedicated committee charged with the responsibility of judicious use toward improving the manpower development through education, consolidated improvement on health services, quality constructions and rehabilitation of all government roads, rehabilitation and consolidation of the railway transportation system, housing and good water to all Nigerians etc.

\section{The surplus of refined crude and the growth in GDP as a result of restreamed refineries and the construction of new ones}

The possible restreaming and the construction of new refineries across the nation would result to abundant and availability of PMS and all other refined products (including kerosene, diesel oil etc.). The good news is that the problems of domestic consumption of PMS, kerosene, diesel etc. would be completely resolved. Most importantly, this surplus of refined crude could then be export overseas which would, in turn, increase the nation's gross domestic products (GDP). The increase in the GDP would increase the nation chances to be among the G20 nations by the year 2020, a goal set by the millennium development goal (MDG) policy. ${ }^{8}$

Positive effects of the new refineries: The building of new refineries would create jobs opportunities for our graduates and skilled workers. This is a positive effect of reducing the unemployment which is currently deep-rooting the Nigeria's economy. Secondly, it will also increase the nation net-economies through the subsidiary and all other supporting company that will run the sub-services of the refineries.

Surplus quantities of refined products and pricing: The availability of refined crude all over the nation would equally resolve the current high price of PMS and all other products, using the principles of the law of demand and supply in the modern economics. The possible reductions in the prices of the refined petroleum products at the end of the day would be a considerable effort toward alleviating the current feelings of the masses. Therefore, a net of $905,130 \mathrm{bpd}(140,175$ bpd $+764,955$ bpd) would be achieved toward the domestic consumption and possible exportation of refined crude. ${ }^{9}$ 


\section{Conclusion}

The values of deregulation and diversification of the downstream sector of the nation's economy remain the best option to achieve efficiency in process petroleum refining. Amongst the results of these deregulations is the surplus availability of refined products which will solve the domestic consumption problems and in turn exportation of refined crude. The restreaming of the Nigeria refineries to fully operate on design/operating capacities and the constructions of new refineries through foreign investment would be of immense values. However, qualitative and transparent deregulations of the downstream sector can only be achieved through viable policies that represent all the stakeholders in the oil and gas sector. ${ }^{10,11}$ Therefore, when consolidated refining of oil and gas is achieved, the result of surplus petroleum products, e.g. 905,130 bpd will solve the domestic consumptions, possible reduction in prices of refined products and in turn increase the nation's GDP, due to exportation of refined crude and most importantly our teaming youth will be gainfully employed.

\section{Acknowledgements}

The authors of this paper acknowledge the support of the energy resource research institute, ERRI, University of Leeds, United Kingdom and the NNPC for some of the information used in this report.

\section{Conflict of interest}

The author declares no conflict of interest.

\section{References}

1. NNPC. Nigerian National Petroleum Company NNPC, the Refinery Encyclopedia. Chiyoda Chemical Construction Company. Tokyo, Japan, 1996.
2. Idris MN, Mahmud T, Gibbs BM. Exploitation and Management of Oil and Gas re-sources for industrial and Economic Development. Journal of Research in Engineering, International Research and Development Institute. 2007;4(1).

3. TNT. The Nigerian Tribune, The Nigerian Population too large for comfort-NPC, as at 31, October 2011 African Newspapers of Nigeria Plc. 2011.

4. DT. Daily Trust Newspapers. The daily newspaper: Nigeria lost N207bn to strike, statistics bureau report. 2012.19 p.

5. DT. Daily Trust Newspapers. The daily newspaper: Reviews on the removal of petroleum subsidy. 2012.

6. NNPC. NNPC. 2016.

7. News Watch Magazines. The new year bombshell and Jonathan's Controversial New Year Gift. 2012.

8. The Guardian Newspapers. The Daily newspaper: On the Removal of Petroleum Subsidy. 2012.

9. Idris MN. Hydrodynamics and Process Modelling of Fluid Catalytic Cracking Reactors. UK: University of Leeds; 2010.

10. Hannah Faal, Clare Gilbert. Convincing governments to act: VISION 2020 and the Millennium Development Goals. Community Eye Health. 2007;20(64):62-64.

11. UN. We End Poverty Target 7.D: Achieve, by 2020, a significant improvement in the lives of at least 100 million slum dwellers. United Nations Headquarter, USA, 2015. 